\title{
Climate Change Analysis (Monthly Rainfall) on Palembang Duku Production (Lansium domesticum Corr)
}

\author{
Ratih Wijayanti ${ }^{*}$, Edward Saleh ${ }^{2}$, Herlina Hanum $^{3}$, Nabila Aprianti ${ }^{4}$ \\ ${ }^{1}$ Environmental Management Program, Graduate School, Universitas Sriwijaya, Palembang, 30139, South \\ Sumatera, Indonesia \\ ${ }^{2}$ Agricultural Engineering, Faculty Agriculture, Universitas Sriwijaya, Ogan Ilir, South Sumatera, Indonesia \\ ${ }^{3}$ Department of Mathematics, Faculty of Mathematics and Natural Sciences, Universitas Sriwijaya, Ogan Ilir, \\ South Sumatera, Indonesia \\ ${ }^{4}$ Doctoral Program of Environmental Science, Graduate School, Universitas Sriwijaya, Palembang 30139, South \\ Sumatera, Indonesia \\ *corresponding author email: widjayanti.ratih@gmail.com
}

\begin{tabular}{llll} 
Article history & & \\
\hline Received & Received in revised form & Accepted & Available online \\
14 May 2020 & 19 May 2020 & 20 July 2020 & 31 August 2020 \\
\hline
\end{tabular}

Abstract: Climate is one of the conditions needed by plants to increase production. Climate change, especially on rainfall has a significant effect on agriculture because it has a strong dependence on the climate element. Rainfall is one of the climate factors that play a role in supporting the availability of water. Conditions in areas with high rainfall intensity can cause the loss of flowers and fruit, and if there is a long dry season it will affect flowering on Lancium domesticum plants. This study aimed to determine the effect of rainfall on $L$. domesticum production for 10 years (2010-2019). The study was conducted in OKU and OKI Regencies. The analytical method used is multiple linear analysis and correlation analysis. From multiple linear analysis and correlation analysis results, there was a fluctuation in the intensity of rainfall for 10 years (2010-2019). Based on the regression analysis, rainfall in June for OKU Regency had a significant effect on $L$. domesticum production while for OKI Regency the significance occurred in December.

Key words : Climate Change, Duku Production, Schmidt Ferguson, rainfall

\begin{abstract}
Abstrak: Iklim merupakan salah satu syarat yang dibutuhkan tanaman untuk meningkatkan hasil produksi. Perubahan iklim khususnya curah hujan mempunyai pengaruh yang signifikan terhadap pertanian karena mempunyai ketergantungan yang kuat terhadap unsur iklim. Curah hujan adalah salah satu faktor unsur iklim yang berperan dalam mendukung ketersediaan air. Kondisi daerah dengan intensitas curah hujan yang tinggi dapat menyebabkan gugurnya bunga dan buah, dan jika terjadi musim kering yang lama maka akan mempengaruhi pembungaan pada tanaman. Penelitian ini bertujuan untuk mengetahui pengaruh curah hujan terhadap produksi L. domesticum selama 10 tahun (2010-2019). Penelitian dilakukan di Kabupaten OKU dan OKI. Metode analisis yang digunakan adalah analisis linier berganda dan analisis korelasi. Dari hasil analisis linier berganda dan hasil analisis korelasi, penelitian menunjukan terjadinya fluktuatif intensitas curah hujan selam 10 tahun (2010-2019). Hasil regresi menunjukan bahwa variabel curah hujan pada bulan Juni untuk Kabupaten OKU signifikan terhadap produksi duku sedangkan untuk Kabupaten OKI signifikans terjadi pada bulan Desember.

Kata kunci : Perubahan Iklim, Produksi Duku, Schmidt Ferguson, Curah Hujan.
\end{abstract}

\section{Introduction}

Climate is an important factor in supporting plant growth and production. One element of climate that plays an important role is rainfall, therefore accurate rainfall information is needed in supporting agriculture and plantations [1]. At present, climate change can cause negative impacts on the environment, namely drought, floods, and heavy rainfall. The failure of flowering plants due to climate change, especially rainfall has an impact on crop yields and annual production [2].

Lansium domesticum Corr is a plant that grows in the tropics commonly known as duku, koskosan, langsat (Indonesia), duku, langsak (Burmese), langsat, duku (English), Filipino lanzon, lansones, lansone fruits (Filipino), langseh, Langsep elderly (Malaysia), duku, 
longkong, langsa (Thailand), and bon-bon (Vietnam) [3]. Lancium domesticum plants bear fruit seasonally and only once a year, and have variations in the characteristics of the tree and fruit, so that among the Indonesian people duku is known by various names, but in general it is better known as duku [4].

Duku has brought prospects to be developed because it has high market potential and has quite good economic value both in Indonesia and in other Southeast Asian Countries. The total duku production in Indonesia reached 228,817 tons which placed the duku in the twelfth position of fruit production in Indonesia [5]. Duku production in Southern Sumatera in 2011 reached 8419.1 tons [6].

The problems and obstacles faced in duku agribusiness in Indonesia are the continuous supply of fruit. Duku plants have flowering and fruiting properties that are unstable or bear fruit one year and bear little or no fruit the following year (biannual bearing). Environmental factors, especially microclimate and plant endogenous factors are biannual bearing properties that affect duku production [7].

In the cultivation of duku plants, land resources and climate are factors that greatly influence the growth and production of duku [8]. The success of the development and cultivation of a commodity is determined by cultivation technology and the suitability of land resources and climate in order to achieve the expected amount and quality [9].

Climate change research results for the province of South Sumatra showed an increase in temperature of $0.4-0.6{ }^{\circ} \mathrm{C}$, while rainfall fell by 0 to $197 \mathrm{~mm}$. Changes in rainfall and air temperature affect changes in hitergraf and Oldeman classification which tends to be drier. Climate change certainly has a significant impact on crop water availability, planting season, early planting, and crop cultivation techniques on a land [10].

The decline in duku production is due to a large number of farmers experiencing crop failures due to climate and non-climate factors. Related to the relationship of climate conditions, especially rainfall, it is necessary to conduct research aimed at determining the extent of the relationship of climate with the pattern of Palembang duku production, especially in Ogan Komering Ulu (OKU) and Ogan Komering Ilir (OKI) Regencies in South Sumatra Province, and whether there is a relationship between the issue of decreasing duku production in the Regency with climate change, especially rainfall.

\section{Materials and Methods}

Analysis of climate change on $L$. domesticum production was carried out in several central regions of Palembang duku production namely OKU and OKI Regencies, South Sumatra. The study involved historical data related to climate data and duku production data, namely monthly rainfall data for the period 2010 to 2019 from BMKG Station and rain posts scattered in the OKI and OKU Regencies.

\subsection{Location}

The study is located in South Sumatra Province in selected districts namely OKI Regency which is located between $104^{\circ} 20^{\prime}$ and $106^{\circ} 00^{\prime}$ East Longitude (ET) and $2^{\circ} 30^{\prime}$ to $4^{\circ} 15^{\prime}$ South Latitude (SL), and Regency OKU is located between 103 $40^{\prime}$ East Longitude (ET) and $3^{\circ} 45^{\prime}$ to $4^{\circ} 55^{\prime}$ South Latitude (SL). The selection of the two regencies and sampling locations is based on the annual duku production area statistics in South Sumatra.

\subsection{Procedure}

This research used quantitative and qualitative descriptive analysis then analyzed by multiple linear analysis and correlations described descriptively. Multiple linear regression analysis is used to determine the functional influence between the dependent variable and the independent variable while the correlation analysis is used to see the strengths and weaknesses of the relationship between the independent and dependent variables between production variables. The dependent variable in this study is the production of duku (tons) notified by $\mathrm{Y}$. While the dependent variable is notated with $\mathrm{X}$ which is the monthly rainfall variable. The functional influence of monthly rainfall variables on production is analyzed using Equation 1.

$$
\mathrm{Y}=\mathrm{a}+\mathrm{b}_{1} \mathrm{X}_{1}+\mathrm{b}_{2} \mathrm{X}_{2}+\ldots+\mathrm{b}_{\mathrm{n}} \mathrm{X}_{\mathrm{n}}+\varepsilon
$$

(1)

where:

$\mathrm{Y} \quad$ : Total production of duku

a : intercept of the line on the $\mathrm{Y}$ axis

b : linear regression coefficient

$\mathrm{X}_{1}$ : monthly rainfall $\mathrm{X}_{1}-\mathrm{X}_{9}$

$\varepsilon \quad:$ error

Determination of climate type is calculated according to Schmidt Fergusson's classification (Equation 2). The data needed is monthly data per 10 years which is used to determine the type of Dry Month (DM), Humid Month (HM), and Wet month (WM) each year.

$$
\mathrm{Q}=\frac{\text { meanDM }}{\text { meanWM }} 100 \%
$$

The DM criteria are monthly with a dry rainfall of $60 \mathrm{~mm}$ while $\mathrm{HM}$ with rainfall between 60$100 \mathrm{~mm}$, and a WM greater than $100 \mathrm{~mm}$. DM, HM, and $\mathrm{WM}$ during the observation period are summed and averaged. 
3. Results and Discussions

\subsection{Rainfall in $O K U$ and OKI Regencies}

Rainfall is the most basic climate element in forming the climate type of a region. Based on a study of the Kenten BMKG Palembang data, it is noted that there are fluctuations for rainfall each year in OKU and OKI districts (Figure 1).

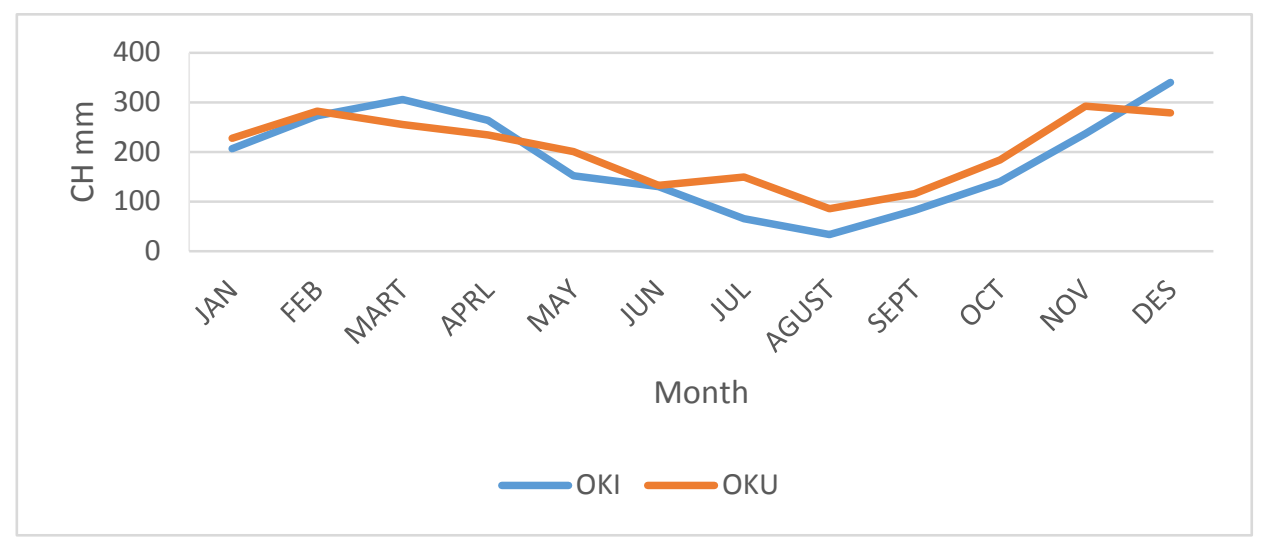

Figure 1. Monthly Rainfall of OKU Regency during 2010 - 2019

Figure 1 showed that in 2010-2019 for the OKI district the highest rainfall intensity occurred in December and the lowest rainfall intensity occurred in August because there were no rainy days in that month. The highest rainfall intensity for OKU Regency was in November and the lowest rainfall intensity occurred was in August, where there was no rainy day in that month.

The maximum duku plant rainfall is 3500 $\mathrm{mm} /$ year, while the minimum rainfall is 2000 $\mathrm{mm} /$ year [3]. Rainfall in OKU and OKI Regencies did not show significant differences (Figure 2). The highest rainfall in OKI occurred in $2013(2,819 \mathrm{~mm})$, while in OKU it occurred in $2010(4,157.5 \mathrm{~mm})$ (Figure 2). The lowest rainfall intensity occurred in $2015(1,464 \mathrm{~mm})$ at OKI Regency and in 2014 $(1,512.5 \mathrm{~mm})$ at $\mathrm{OKU}$ Regency. Thus the annual rainfall intensity is suitable for the growth of $L$. domesticum.

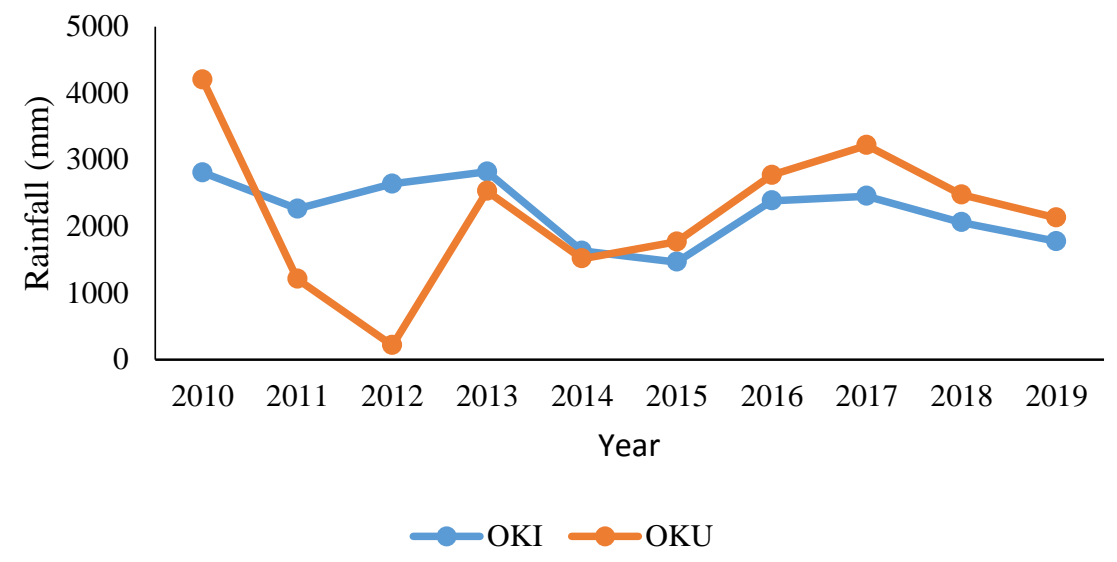

Figure 2. Rainfall in OKI, OKU Regencies (2010-2019)

\subsection{Schmidt Ferguson (SF) Classification}

The Schmidt Ferguson method (1951) is a comparison value $(\mathrm{Q})$ between the average dry month (DM) and the average number of wet months (WM) in the study year (Table 2). Based on climate classification (equation 1) the distribution of rainfall over 10 years (2010-2019) in the OKI and OKU districts is a wet climate type $(\mathrm{B})$ where the $\mathrm{Q}$ value for OKI is 0.3209 and 0.168 for OKU (Table 2).

Table 2. SF climate classification of OKI and OKU regencies

\begin{tabular}{|c|c|c|c|c|c|c|}
\hline \multirow[b]{2}{*}{ Regency } & \multirow[b]{2}{*}{ Rain Post } & \multirow[b]{2}{*}{ Rainfall } & \multicolumn{3}{|c|}{ Average } & \multirow[b]{2}{*}{$\begin{array}{l}\text { Climate } \\
\text { Type (SF) }\end{array}$} \\
\hline & & & $\begin{array}{c}\text { DM } \\
\text { (dry month) }\end{array}$ & $\begin{array}{c}\mathrm{HM} \\
\text { (humid month) }\end{array}$ & $\begin{array}{c}\text { WM } \\
\text { (wet month) }\end{array}$ & \\
\hline OKI & Pampangan & $22,283.0$ & 26 & 12 & 81 & B \\
\hline OKU & Lubuk Batang & $22,006.4$ & 15 & 15 & 89 & B \\
\hline
\end{tabular}


3.3 Duku Production and Annual Rainfall in $O K U$ and OKI Regencies

Duku production in OKI and OKU regencies over the past 10 years has fluctuated. Duku ton/year productivity data obtained from the Badan Pusat Statistik (BPS) and The Agriculture and Horticultural Service of South Sumatera Province in Table 2. Duku fruit production results vary a tendency of two times fruit in one year, the climate especially rainfall can affect duku production [11].

L. domesticum in OKI and OKU Regencies has two local names namely Duku and Langsak whose distribution is located along the Komering, Ogan, Lematang and Musi Watersheds and along the main road and community plantations. Duku is planted together with other plants or polyculture [12].

Table 2. Duku Productivity for 10 Years (2010-2019)

\begin{tabular}{crr}
\hline \multirow{2}{*}{ Year } & \multicolumn{2}{c}{ Productivity (tons/year) } \\
\cline { 2 - 3 } & \multicolumn{1}{c}{ OKU } & \multicolumn{1}{c}{ OKI } \\
\hline 2010 & $69,263.0$ & $18,794.0$ \\
2011 & $5,923.0$ & $164,322.0$ \\
2012 & $14,027.0$ & $626,578.0$ \\
2013 & $1,702.0$ & 978.0 \\
2014 & $4,814.0$ & $6,412.0$ \\
2015 & $9,736.0$ & $10,916.0$ \\
2016 & $1,029.0$ & $5,814.0$ \\
2017 & $2,604.5$ & $3,083.4$ \\
2018 & $7,248.8$ & $23,869.3$ \\
2019 & $5,523.4$ & $3,217.3$ \\
\hline
\end{tabular}

The average duku production for each regency for 10 years (2010-2019) is based on productivity of 116,899.64 tons for OKU Regency while 861,088.43 tons for OKI Regency. Duku production results in each district tend to fluctuate each year. The highest duku production level for the two districts, OKI was 626,578 tons, and the highest production in OKU Regency occurred in 2010 with 69,263 tons.

\subsection{Multiple Correlation Analysis $(R)$}

Correlation analysis is used to see the strengths and weaknesses of the relationship between independent and dependent variables (Table 3), the following is the interpretation of $R$ value. If the correlation value $-1 \leq \mathrm{r} \leq 1$ where $\mathrm{R}=|\mathrm{r}| \rightarrow 0 \leq \mathrm{R} \leq$ 1 , then the results of the correlation analysis are obtained in Table 7.

Table 3. Interpretation of $\mathrm{R}$ values in correlation analysis

\begin{tabular}{cc}
\hline R Value & Interpretation \\
\hline $0.01-0.20$ & Very Weak \\
$0.21-2.40$ & Weak \\
$0.41-0.60$ & Rather Weak \\
$0.61-0.80$ & Rather \\
$0.81-0.99$ & Strong \\
1.00 & Very Strong \\
\hline
\end{tabular}

The results of correlation analysis (Table 4) for OKU Regency show that rainfall variables have a strong closeness of 0.844 . The $\mathrm{R}$ value has an interpretation that the rainfall variable has a strong influence on the achievement of duku productivity. Significance value is smaller than $\alpha 1 \%(\operatorname{Sig}<\alpha 0.01)$ and other correlation analysis show that there is no real effect on the productivity of duku because the significance value is greater than $\alpha 1 \%(\operatorname{Sig}<\alpha 0.01)$.

Correlation analysis (Table 4) in OKI Regency shows the rainfall variable has a strong relationship of 0.832. $\mathrm{R}$ value has an interpretation of rainfall variables that have a strong influence on the productivity of the duku, because the significance value is smaller than $\alpha 1 \%(\operatorname{Sig}<\alpha 0.01)$ and the results of other correlation analyzes show no real effect on the duku productivity due to the significance value greater than $\alpha 1 \%(\operatorname{Sig}<\alpha 0.01)$.

Table 4. The Results of the Correlation Analysis (R) are Significant between the Monthly Rainfall and Duku Production.

\begin{tabular}{|c|c|c|c|}
\hline \multirow{2}{*}{ Month } & \multirow{2}{*}{ Correlation } & \multicolumn{2}{|c|}{ Regency } \\
\hline & & OKI & OKU \\
\hline \multirow[t]{2}{*}{ Aprl } & Correlation & -0.242 & 0.408 \\
\hline & Sig. & 0.501 & 0.241 \\
\hline \multirow[t]{2}{*}{ Mei } & Correlation & 0.107 & 0.525 \\
\hline & Sig. & 0.768 & 0.12 \\
\hline \multirow[t]{2}{*}{ Jun } & Correlation & -0.543 & 0.844 \\
\hline & Sig. & 0.105 & 0.002 \\
\hline \multirow[t]{2}{*}{ Jul } & Correlation & 0.299 & -0.128 \\
\hline & Sig. & 0.401 & 0.724 \\
\hline \multirow[t]{2}{*}{ Agst } & Correlation & -0.464 & 0.364 \\
\hline & Sig. & 0.176 & 0.301 \\
\hline \multirow[t]{2}{*}{ Sept } & Correlation & -0.226 & 0.298 \\
\hline & Sig. & 0.53 & 0.402 \\
\hline \multirow[t]{2}{*}{ Okt } & Correlation & -0.001 & 0.386 \\
\hline & Sig. & 0.998 & 0.27 \\
\hline \multirow[t]{2}{*}{ Nov } & Correlation & 0.313 & 0.543 \\
\hline & Sig. & 0.379 & 0.105 \\
\hline \multirow[t]{2}{*}{ Des } & Correlation & 0.832 & -0.361 \\
\hline & Sig. & 0.003 & 0.305 \\
\hline
\end{tabular}

3.5 Multiple linear analysis

Multiple linear analysis is used to determine the effect (positive or real) of monthly rainfall on duku production (Table 3) which can be developed into a linear regression equation model (Equation 3 ).

Table 5. Analysis of multiple linear test models in 2010-2019

\begin{tabular}{clrr}
\hline \multirow{2}{*}{ Regency } & \multirow{2}{*}{ Model } & $\begin{array}{c}\text { Coefficients } \\
\text { Regression }\end{array}$ & \multicolumn{1}{c}{ Sig } \\
\hline \multirow{2}{*}{ OKI } & (Constant) & -221753.356 & 0.26 \\
& December & 905.266 & 0.003 \\
\hline \multirow{2}{*}{ OKU } & (Constant) & -38691.151 & 0.023 \\
& June & 434.207 & 0.002 \\
\hline \multirow{2}{*}{ Predictor }
\end{tabular}

a. $\quad$ Predictor (Constant) : June, December

b. Dependent Variable : Production 
Production $(\mathrm{Y})=-38691.151+434.207+\epsilon$

From equation 3, a constant of -38691.151 is obtained which if the independent variable in June is considered constant, it can be predicted that the production of $L$. domesticum has a value of 38691.151. The variable regression coefficient of June at 434.207 indicated that if the value of the June variable increases by one unit and the other is constant, it can be predicted that the June value will increase by 434.207 .

Through multiple linear regression analysis to determine the effect of monthly rainfall on $L$. domesticum production in OKI Regency, equation 4 is obtained.

$Y=-221,753.356+905.266+\epsilon$

From equation 4 , a constant value of $221,753.356$ is obtained. The variable coefficient $(\mathrm{X})$ of December from multiple linear regression was

Table 7. Statistical Analysis of the F-Test

\begin{tabular}{cccc}
\hline Regency & Variable & F-Count & Sig \\
\hline OKU & $\begin{array}{c}\text { (Constant) } \\
\text { RF June }\end{array}$ & 19.760 & 0.002 \\
OKI & $\begin{array}{c}\text { (Constant) } \\
\text { RF Dec }\end{array}$ & 18.051 & 0.003 \\
\hline
\end{tabular}

The F count for OKU Regency is 19.760 with a $\mathrm{CH}$ probability of June of 0.002 with a value $<0.05$ (Table 7). The independent variable that is June rainfall has a significant simultaneous effect (together) on the growth of duku production. The results of the analysis for OKI Regency obtained an $\mathrm{F}$ count of 18.051 with a probability of 0.003 whose value $<0.05$. The independent variable, which is December rainfall, has a significant (positive) effect simultaneously on duku production.

Table 8. Coefficient Values of Multiple Linear Regression Equations in Duku Production (2010-2019)

\begin{tabular}{cccc}
\hline \multirow{2}{*}{ Regency } & \multicolumn{3}{c}{ Coefficient Value } \\
\cline { 2 - 4 } & $\mathrm{R}$ & $\mathrm{R}^{2}$ & Adjusted $\mathrm{R}^{2}$ \\
\hline OKU & 0.844 & 0.712 & 0.676 \\
OKI & 0.832 & 0.693 & 0.655 \\
\hline
\end{tabular}

Based on Table 6 for OKU Regency, the coefficient (R) is $84.4 \%$, the coefficient of determination $\left(\mathrm{R}^{2}\right)$ is $71.2 \%$ and the corrected determination coefficient (Adjusted $\mathrm{R}^{2}$ ) is $67.6 \%$. The coefficient of determination $\left(\mathrm{R}^{2}\right)$ indicates that $71.2 \%$ of productivity can be explained by rainfall variables that occur and the remaining $28.8 \%$ is explained by other variables not included in the model. obtained at 905.266 so that if the December variable value increased by one unit and the others were constant, it can be predicted that the December variable value increased by 905.266 .

Table 6. T-Partial Test Results of Rainfall in the Production of Duku (2010-2019)

\begin{tabular}{cccc}
\hline Rgency & Variable & t-count & Sig \\
\hline \multirow{2}{*}{ OKU } & (Constant) & -2.794 & 0.023 \\
& CH June & 4.445 & 0.002 \\
\multirow{2}{*}{ OKI } & (Constant) & -2.732 & 0.26 \\
& CH Des & 4.249 & 0.003 \\
\hline
\end{tabular}

T-test results in OKU Regency in June obtained the t-count of 4,445 with a probability of 0.002 whose value is $<0.05$ (Table 4). There was a significant positive effect between June on duku production. The test results of the effect of rainfall on duku production for OKI Regency based on the calculated t-value from December was 4,249 with a probability value (Sig) of $0.003(<0.05)$. There was a significant positive effect in December partially on duku production.

Analysis of the coefficient (R) of OKI Regency showed a value of $83.2 \%$, a coefficient of determination $\left(\mathrm{R}^{2}\right)$ of $69.3 \%$, and a corrected determination coefficient (Adjusted $\mathrm{R}^{2}$ ) of $65.5 \%$. The coefficient of determination $\left(\mathrm{R}^{2}\right)$ indicates that $69.3 \%$ of productivity can be explained by rainfall variables and the remaining $30.7 \%$ is explained by other variables not included in the model.

Duku production centers in two districts have different rainfall intensities. Based on the regression analysis, the regression coefficient value of rainfall for 10 years (2010-2019) L. domesticum OKU District has a real value in June of duku production with a significant value of $0.002<0.05$ and OKI Regency has a real value in December for duku production. The significant value of $0.003<0.05$, because every increase of one millimeter of rainfall and the other is constant, it can affect the yield of duku. The variable regression coefficient of June at 434.207 indicated that if the value of the June variable increases by one unit and the other is constant, it can be predicted that the June value will increase by 434.207 . The variable coefficient of December from multiple linear regression was obtained at 905.266 so that if the December variable value increased by one unit and the others were constant, it can be predicted that the December variable value increased by 905.266 (Table $5)$.

Rainfall parameters have not only directly affected its production of duku, the concentration of rainfall needed by duku plants is the optimum rainfall for growth and development [13]. From the regression results, it comes the most dominant monthly rainfall relationships, which is the value of the cocentralization of the June rainfall for our district and December for the OKI district. Regression analysis results from every increase in precipitation 
cogeneration with optimum intensity in June and December, and the number of my two production increases. It shows an effect of rainfall on the duku productivity in both the districts of OKU and OKI.

The flower fall in tropical plants is very high, the heavy rainfall in flowering and fruit phases can cause the loss of flowers and potential fruits, in the process of ripening fruit from a high rainfall can accelerate fruit decay and can damage the fruit's quality [14]. The number of fruit remaining after the fall is called a fruit set, fruit growth and development occur when the average rainfall increases, so that sufficient groundwater is available to support profitcell division and optimum growth ([7].

Lizawati [7] says, the beginning of the duku plant trubus occurred in May and the culminated in July, during the August-September period is the end of the duku plant trubus, because the duku plants needs dry period for flower induction. Flowering occurs in early October, late in the dry season or early in the rainy season. So when there is a dry month or a dry season period, where water is available for the duku growth process is sufficient and not all the flower buds can grow and grow up to anthesis and form fruit.

The productivity problem is essentially how a combination of individual input is used to produce maximum output, in plants production is affected by other factors besides rainfall, biological factors such as soil and natural boundaries, and other climatic factors such as temperature, humidity and also the intensity of sunlight. In addition, other factors that support the growth of plants are good water and air conditions in order to facilitate the absorption of nutrients which can increase plant productivity so that rainfall has no significant or negative effect on duku production [15].

In production, plants are also influenced by factors other than rainfall, biological factors such as soil and natural boundaries, as well as other climatic factors such as temperature, humidity, and also the intensity of sunlight. Another factor that supports growth for plants is good water and air management so that it can facilitate the absorption of nutrients that can increase crop productivity so that rainfall does not have a significant or negative effect on duku production and the decline in duku Komering production is caused by a change in mixed cropping patterns to a monoculture pattern and decrease in the quantity of duku crop land area caused by decreased interest in planting due to long fruiting ages [16].

\section{Conclusion}

There was a fluctuation in the value of the intensity of monthly rainfall and duku production in the OKI and OKU districts during 2010-2019 with Schmidt Ferguson climate classification is a wet climate type. The results of multiple linier regression showed for OKU district rainfall in June significantly affected the production of duku with $\mathrm{R}^{2} 71.2 \%$ and OKI regency the significant rainfall is December rainfall with $R^{2} 69.3 \%$ with significant value $<0.05$. Because in OKU Regency variable regression coefficient of June at 434.207 indicated that if the value of the June variable increases by one unit and the other is constant, it can be predicted that the June value will increase by 434.207 and in OKI Regency variable coefficient (X) of December from multiple linear regression was obtained at 905.266 so that if the December variable value increased by one unit and the others were constant, it can be predicted that the December variable value increased by 905.266.

\section{Acknowledgments}

The authors thank the Indonesian Agency for Meteorology, Climatology, and Geophysics (BMKG), Kenten Station, Palembang, South Sumatera, and the South Sumatera Department of Agriculture and Horticulture for providing rainfall and duku production historical data.

\section{References}

[1] T. Iizumi and N. Ramankutty. 2015. "How do weather and climate in fl uence cropping area and intensity?," Glob. Food Sec., vol. 4, pp. 46-50.

[2] S. Mar, H. Nomura, Y. Takahashi, K. Ogata, and M. Yabe. 2018. "Impact of Erratic Rainfall from Climate Change on Pulse Production Efficiency in Lower Myanmar," pp. 1-16.

[3] K. Lim, T. 2012. Edible Medicinal and NonMedicinal Plants. $3^{\text {th }}$ vol. Fruits. Spinger. New York.

[4] L. Hanum, R. S. Kasiamdari, Santosa, and Rugayah, "Genetic Relatedness among Duku, Kokosan , and Pisitan in Indonesia Based on Random Ampli fi ed Polymorphic DNA Markers," vol. 17, no. 2, pp. 121-131, 2012.

[5] BPS, STATISTIK INDONESIA. 2010.

[6] Katalog BPS SUMSEL. 2012.

[7] Lizawati, B. Ichwan, Gusniwati, Neliyati1, and M. Zuhdi. 2013. "Fenologi Pertumbuhan Vegetatif Dan Generatif Tanaman Duku Vareitas Kumpeh Pada Berbagai Umur," vol. 2, no. 1, pp. 16-26.

[8] H. Purnama, A. Sutandi, K. Gandasasmita, and Widiatmaka. 2010. "Karakteristik Lahan Pada Pertanaman Duku ( Lansium domesticum Corr ) Provinsi Jambi," vol. 12, no. 2, pp. 18-24.

[9] Food and Agriculture Organization of the United Nations. 2011. "The State of the World's Land and Water Resources for Food and Aagriculture, Managing systems at risk. Food and Agriculture Organization of the United Nations, Rome and Earthscan, London. 
[10] Ruminta and Handoko. 2016. "Vurnerability assessment of climate change on agriculture sector in the South Sumatra province , Indonesia," vol. 8, no. November, pp. 31-42.

[11] T. Mayanti, 2009. Kandungan Kimia dan Bioaktivitas Tanaman Duku.

[12] U. Kalsum and Arifin. 2011. "Review of Fruit Characteristic Duku Variety Palembang and Variety Rasuan Growing in the Flow of River (DAS)," pp. 93-102.

[13] F. Arifianto and Y. Koesmaryono. 2016. "Karakterisasi Tingkat Produksi Duku Berbasis Pewilayahan Hujan di Provinsi Jambi Characterization of Duku Production Levels Based on Zoning of Rainfall Pattern in Jambi Province," vol. 7, no. 2, pp. 121-128. E. Gunawan. 2007. "Hubungan Agroklimat Dengan Fenofisiologi Tanaman dan Kualitas Buah Manggis di Lima Sentra Produksi di Pulau Jawa. Program Studi Agronomi Sekolah Pascasarjana."

[15] H. Margareth Thacher Manurung, Irsal,. 2015. "Pengaruh Curah Hujan dan Hari Hujan Terhadap Produksi Tanaman Karet (Hevea brasiliensis Muell-Arg) Umur 6,10 dan 14 Tahun pada PT. Bridgestone Sumatera Estate Dolok Merangir," vol. 3, no. 2337, pp. 564 573.

[16] S. Aminah. 2002. "Dampak Perubahan Agroklimat Pada Kualitas, Kuantitas, dan Budidaya Duku (Lansium domesticum Corr)," pp.

$1-3$ 